\title{
MANAJEMEN KINERJA APARATUR SIPIL NEGARA DI INDONESIA: SEBUAH KONSEP MANAJEMEN PUBLIK BARU
}

\author{
Bertha Lubis \\ Institut Pemerintahan Dalam Negeri (IPDN) \\ Email: bertha.lubis@ipdn.ac.id
}

\begin{abstract}
Abstrak
Manajemen publik baru merupakan konsep baru dalam ilmu administrasi publik. Konsep ini berfokus pada orientasi hasil, transparansi dan akuntabilitas layanan administrasi. Manajemen kinerja adalah kunci untuk orientasi hasil. Sistem Manajemen Kinerja adalah catatan masukan, proses, keluaran dan hasil dari prosedur pemerintah. Ini membantu untuk mengevaluasi dan memantau kemajuan pemerintah menuju pencapaian tujuan. Penelitian ini bertujuan untuk memperkenalkan konsep manajemen kinerja aparatur sipil negara di Indonesia sebagai konsep manajemen publik baru. Penelitian memakai metode kualitatif dalam menganalisa obyek penelitian. Hasil penelitian menunjukkan bahwa birokrasi yang rumit dan masih kurangnya kualitas pelayanan publik telah menjadi kutukan ilmu administrasi publik di Indonesia. Manajemen kinerja ASN sebagai konsep manajemen publik baru yang berbasis kinerja merupakan suatu terobosan yang mampu meningkatkan kinerja ASN yang pada akhirnya berdampak pada kinerja pelayanan pubik.
\end{abstract}

Kata Kunci: Manajemen Kinerja, Administrasi Publik, Aparatur Sipil Negara.

\begin{abstract}
New public management is a new concept in public administration science. This concept is results oriented, transparency and accountability of administrative services. Performance management is the key to results orientation. The Performance Management System is a record of the inputs, processes, outputs and results of government procedures. This helps to achieve the government's progress towards the goals. The Research goals to introduce the concept of performance management of the state civil servants in Indonesia as a new public management concept. The research used qualitative methods in the analysis of the research object. The results show that the bureaucracy that is complicated and still lacks quality of public services has become the curse of public administration science in Indonesia. The ASN performance management concept as a new performance-based public management is a breakthrough that can improve ASN performance which in the end has an impact on the performance of public services.
\end{abstract}

Keywords: Performance Management, Public Administration, State Civil Apparatus.

\section{A. PENDAHULUAN}

Reformasi baru dalam administrasi publik merupakan adaptasi dari prinsip-prinsip manajemen publik baru dalam suatu administrasi (Dunleavy \& Hood, 1994). Prinsip-prinsip ini terutama berfokus pada orientasi hasil, transparansi dan akuntabilitas layanan 
administrasi. Manajemen kinerja adalah kunci untuk orientasi hasil (Schedler \& Proeller, 2000).

Ada dua jenis sistem Administrasi untuk mengelola layanan sipil yaitu Model tradisional dari kontrol administratif hirarkis terpusat dan sebuah model reformasi yang menyerahkan tanggung jawab keuangan dan personalia yang lebih besar ke bawah garis administrasi dan bergantung pada kinerja untuk mengarahkan perilaku pegawai negeri (Nunberg, 1994).

Manajemen kinerja melibatkan penetapan tujuan dan target kinerja untuk skema, program dan proyek, memantau dan melaporkan tingkat kinerja dan untuk memberikan informasi untuk pengambilan keputusan dan audit di masa depan (Ruky, 2002).

Sekarang pertanyaannya apakah ada sistem manajemen kinerja pada aparatur sipil negara Indonesia, Jawabannya belum ada, kami memiliki sistem penilaian kinerja akan tetapi kami tidak punya Sistem Manajemen Kinerja. Kami memiliki alat konvensional untuk mengelola kinerja seperti latihan anggaran, laporan tahunan yang diterbitkan oleh Kementerian/departemen, anggaran kinerja dan dokumentasi untuk anggaran hasil (Kadarisman, 2018).

Struktur tata kelola di Indonesa dicirikan oleh pendekatan berbasis aturan. Fokus dari layanan sipil di Indonesia adalah pada proses regulasi, kepatuhan dengan standar dan aturan yang ditentukan secara terpusat. Ukuran kinerja utama adalah jumlah yang dibelanjakan dan keberhasilan skema, program, dan proyek.Untuk meningkatkan kinerja aparatur sipil negara dan meminimalkan sifat birokrasi yang khas dari aparatur sipil negara maka diperlukan sistem Manajemen Kinerja bagi aparatur sipil negara (Fatya, 2019).

\section{B. METODE}

Didalam penelitian ini metode yang dipakai adalah metode kualitatif yatu penelitian yang dipakai untuk meneliti pada keadaan objek ilmiah dimana instrument kuncinya adalah peneliti itu sendiri (Sugiyono, 2005). Sementara Moleong (2005) menejelaskan, penelitian kualitatif merupakan pendekatan yang mempunyai makna untuk memahami perilaku, motivasi, persepsi, tingkah laku yang dialami subyek penelitian secara holistic dan digambarkan Dalam bentuk kata atau bahasa dalam konteks khusus dengan menggunakan berbagai peendekatan ilmiah (Cassel dkk., 2017). 


\section{HASIL DAN PEMBAHASAN}

\section{Sistem Manajemen Kinerja}

Sementara diasumsikan bahwa manajemen kinerja adalah penemuan modern, catatan menunjukkan bahwa Dewan New York menganalisis data dan menetapkan target untuk aktivitas laporan sejarah dan memperkirakan kinerja masa depan di awal 1900-an (Soltani dkk, 2003), meskipun istilah "manajemen kinerja" adalah tidak digunakan sampai tahun 1970-an (Armstrong \& Baron, 2005). Sekarang merupakan aspek mapan dari manajemen sektor publik dengan jurnal yang menghasilkan edisi khusus tentang subjek (Ferlie dan Steane, 2002). Meskipun tingkat minat yang tinggi ini, Brown (2005) mencatat setidaknya 17 alasan berbeda (beberapa bertentangan) untuk memperkenalkan manajemen kinerja, sehingga memberikan indikasi tingkat kebingungan seputar subjek.

Manajemen kinerja mencakup semua aspek bisnis. Dalam tinjauan kutipan mereka, Marr dan Schiuma (2003) menemukan kontributor dari berbagai bidang subjek termasuk manajemen, manajemen operasi, pemasaran, keuangan, akuntansi, ekonomi, MSDM, manajemen sektor public dan perilaku organisasi. Namun ada sangat sedikit pekerjaan lintas disiplin, dengan penulis yang berbeda hanya menyoroti aspek manajemen kinerja yang mereka rasa penting dalam penyempitan disiplin mereka (Priansa, 2017).

Teori mengemukakan komponen utama dari sistem manajemen kinerja yang berhasil sebagai berikut:

a. Penyelarasan sistem serta strategi organisasi dan sistem manajemen kinerja yang ada;

b. Konsistensi kepemimpinan;

c. Bukan beban yang digunakan untuk menghukum yang berkinerja buruk akan tetapi sebuah kultur yang dianggap sebagai upaya menambah dan mengenali performa yang baik;

d. Keberadaan pemangku kepentingan; dan

e. Pemantauan terus menerus, umpan balik, penyebaran dan pembelajaran dari hasil (Wang \& Berman, 2001).

Namun, beberapa penulis, seperti Bititci et al. (2006), juga merasa penting bahwa sistem manajemen kinerja tidak statis tetapi menjadi matang seiring dengan perkembangan gaya manajemen dan budaya organisasi.

Sistem Manajemen Kinerja adalah catatan masukan, proses, keluaran dan hasil dari prosedur pemerintah. Ini membantu untuk mengevaluasi dan memantau kemajuan pemerintah menuju pencapaian tujuan. Ukuran kinerja membantu untuk mengkomunikasikan tujuan dan 
sasaran ke bidang utama sehingga mendapatkan kerjasama untuk mencapai tujuan (Alimudin, 2017). Ini membantu untuk memperbaiki kemacetan dalam administrasi dan memandu jika diperlukan untuk memberikan pelatihan kepada pegawai negeri. Ini menunjukkan area yang perlu ditingkatkan. Ini menyentuh proses perencanaan, pelaksanaan, peninjauan, evaluasi dan pelaporan untuk mengukur dampak kebijakan dan program. Ini mendorong pertumbuhan dan pembelajaran, dan mengakui bahwa pembangunan kapasitas dan peningkatan kinerja individu mengarah pada pencapaian tujuan organisasi. Oleh sebab itu dibutuhkan sistem Manajemen Kinerja yang baik bagi ASN (Kristiana, 2015).

Peneliti mengindentifkasi 2 tujuan dalam menmgimplementasikan Manajemen kinerja bagi aparatur sipil negara yaitu :

a. Tujuan Evaluasi

1). Mengevaluasi \& menilai kesiapan individu dalam mengambil tanggung jawab yang lebih besar.

2). Untuk memberi penghargaan kepada individu tentang tingkat kompetensi mereka saat ini dan perlu meningkatkan dengan memberi mereka umpan balik

3). Untuk menghubungkannya dengan kompensasi, penghargaan dan pengembangan karir.

b. Tujuan Pemberdayaan

1).Konseling \& pelatihan kepada bawahan untuk meningkatkan kinerja \& meningkatkan kompetensi

2). Untuk memotivasi bawahan melalui pengakuan dan dukungan

3). Untuk membangun hubungan antara atasan dan bawahan

4). Mendiagnosis kompetensi individu \& organisasi, sehingga dapat diambil tindakan pada area masalah

5). Menetapkan persyaratan pelatihan berdasarkan kompetensi individu.

Manajemen Kinerja adalah inti dari pengelolaan, dan "kendaraan" utama untuk mendapatkan hasil yang diinginkan melalui karyawan di semua tingkatan dalam organisasi. Proses manajemen kinerja memberikan kesempatan kepada karyawan dan manajer kinerja untuk membahas tujuan pengembangan dan bersama-sama membuat rencana untuk mencapai tujuan tersebut (Priansa, 2017). Menurutnya pengembangan harus berkontribusi pada tujuan organisasi dan pertumbuhan profesional pegawai. Dengan tidak adanya sistem seperti itu, pegawai tidak mengetahui dengan jelas harapan pemberi kerja terkait tujuan dan standar / 
target kinerja, yang mengarah pada produktivitas rendah, kesalahan yang mahal, stres, penurunan motivasi, dan konflik.

Sistem Manajemen Kinerja yang Baik menganut Prinsip penting: “Apa yang diukur, diselesaikan". Hari-hari memiliki Sistem Manajemen Kinerja "satu set untuk semua" pada dasarnya cacat dan sudah lama berlalu. Sasaran dan ukuran kinerja harus spesifik untuk kategori pekerjaan dan peran individu.. Manajemen kinerja adalah proses sistematis dimana organisasi melibatkan seluruh sumberdaya yang ada dalam mewujudkan tujuan organisasi. Osborne dan Gaebler dalam bukunya yang berpengaruh, Reinventing Government, mengemukakan konsep orientasi Hasil di beberapa pemerintahan di seluruh dunia (Osborne \& Gabler, 1992). Sasaran dan sasaran karyawan berasal dari departemen mereka, yang pada gilirannya mendukung misi dan sasaran organisasi. Sistem manajemen kinerja yang baik membantu departemen / lembaga untuk memantau dan melaporkan kemajuan menuju tujuan jangka panjang.

Ukuran kinerja membantu departemen untuk mengkomunikasikan tujuan dan prioritas utama mereka, memantau layanan yang mereka berikan dan melaporkan apa yang telah mereka capai. Tetapi di Indonesia tidak ada sistem Manajemen Kinerja yang tepat melainkan hanya memliliki sistem penilaian kinerja .

\section{Manajemen Kinerja Aparatur Sipil Negara di Indonesia}

Sehubungan dengan manajemen sumberdaya manusia aparatur sipil negara pemerintah Indonesia telah mengeluarkan Undang-Undang Nomor 5 Tahun 2014 tentang Aparatur Sipil Negara yang berbunyi manajemen ASN adalah pengelolaan ASN untuk menghasilkan pegawai ASN yang profesional, memiliki nilai dasar, nilai profesi, bebas dari intervensi politik, dan bersih dari praktik korupsi, kolusi, dan nepotisme. Undang undang tersebut memuat banyak penambahan dan perbaikan serta perubahan substansi manajemen ASN yang sebelumnya tidak diatur termasuk dalam penyusunan dan penetapan kebutuhan, pengadaan, pangkat dan jabatan, pengembangan karir, pola karir, promosi, mutasi, penliaian kinerja ,penggajian dan tunjangan, penghargaan, disiplin, kemacetan, jaminan pensiun dan jaminan hari tua, serta perlindungan.

Dalam melakukan penilaian performa aparatur sipil negara didasarkan pada Peraturan Pemerintah Nomor 46 tahun 2011 tentang Penilaian Prestasi Kerja ASN sebagai pengganti Peraturan Pemerintah Nomor 10 Tahun 1979 tentang tentang Penilaian Pelaksanaan Pekerjaan ASN. Peraturan Pemerintah ini bertujuan untuk lebih meningkatkan performa dari 
ASN tersebut. Penilaian kinerja ASN berdasarkan PP No 46/2011 tersebut adalah meliputi sistem prestasi kerja dan sistem karier. Sistem prestasi kerja ASN meliputi dua macam penilaian, yaitu: kompetensi kerja pegawai (SKP) dan perilaku kerja (PK). SKP meliputi perencanaan kerja dan pencapaian target dari ASN tersebut, sedangkan PK adalah penilaian sikap, tindakan dan tingkah laku dari ASN.

Di dalam Peraturan Pemerintah setiap ASN harus menyusun SKP berdasarkan rencana kerja tahunan instansi setiap tahun. SKP ini juga memuat segala bentuk tugas dalam jabatan beserta pencapaian yang telah diperoleh .Apabila ASN tersebut tidak membuat SKP dapat dijatuhi sangsi disiplin yang sesuai dengan ketentuan yang berlaku.. Beberapa aspek seperti orientasi pelayanan, integritas, komitmen, disiplin, kerjasama, dan kepemimpinan termasuk dalam aspek kerja. Khusus manajemen hanya dilakukan terhadap ASN yang menduduki jabatan struktural. Penilaian kinerja ASN dilakukan bulan Desember atau paling lambat pada bulan Januari tahun berikutnya .

Di sektor swasta, kinerja diukur di mana target dapat diukur dalam kaitannya dengan keluaran. Misalnya penjualan dapat diukur, target sektor jasa tercapai dapat diukur. Tetapi dalam kasus output pegawai negeri sipil tidak dapat diukur. Kinerja aparatur sipil negara diukur dari segi hasil yang sulit diukur. Hal tersebut sebagian besar terkait dengan tingkat kepuasan para pencari layanan yaitu warga negara. Sangat sulit untuk memetakan tingkat kepuasan. Karena alasan inilah penilaian kinerja ditekankan pada input yang digunakan dan peningkatan pengeluaran.

Para pegawai negeri sedang mengerjakan program yang berbeda. Untuk kinerja yang lebih baik, setiap departemen / badan pemerintah harus memiliki tujuan dan sasaran yang ditetapkan dengan baik dan dirumuskan dengan baik. Organisasi harus memiliki sense of direction yang berasal dari kebutuhan pengguna dan pemangku kepentingan lainnya. Setiap departemen harus memiliki rencana tindakan yang menyebutkan dengan jelas apa yang ingin dicapai departemen dengan sumber daya yang disediakan, bagaimana mencapainya, apa yang akan disampaikan. Oleh karena itu untuk sistem manajemen kinerja yang lebih baik, perencanaan tindakan adalah penting. Di Indonesia ASN sedang mengerjakan berbagai program. Pekerjaan mereka dapat dialihkan sehingga sangat sulit untuk mengukur kinerja individu. Juga sangat sedikit penekanan yang diberikan pada perencanaan yang tepat. Pedoman atau arahan yang diberikan untuk mencapai target tersebut mungkin membingungkan, tidak memberikan gambaran yang jelas atau mungkin berubah dari waktu 
ke waktu sesuai dengan roda politik, atau sumber daya keuangan yang disediakan mungkin tidak mencukupi dengan pedoman yang tidak jelas untuk penggunaan dana tersebut.

Faktor penting lainnya adalah motivasi kepada ASN untuk kinerja yang lebih baik. Di Indonesia pegawai negeri diberikan kenaikan setiap tahun. Hampir tidak ada insentif pembayaran kinerja yang tersedia bagi mereka. Juga di beberapa departemen, promosi sebagian besar didasarkan pada senioritas, bukan kinerja. Komisi gaji keenam memperkenalkan Skema Insentif Terkait Kinerja di mana karyawan berhak atas tunjangan keuangan berbasis kinerja di atas dan di atas gaji reguler. Karenanya harus ada kenaikan dan promosi berbasis kinerja.

\section{KESIMPULAN}

Birokrasi yang rumit dan penyampaian layanan publik yang tidak memuaskan diakui sebagai kutukan administrasi publik di Indonesia. Meskipun ada banyak faktor kompleks yang bertanggung jawab atas hasil ini, fragmentasi otoritas dan dilusi perintah dan kendali adalah penyebab terdekat yang penting. Untuk meningkatkan kinerja pemerintah harus ada sistem Manajemen Kinerja yang kuat. Untuk memiliki sistem Manajemen kinerja yang lebih baik maka perlu diatasi kekurangan atau keterbatasan yang ada. Target harus dapat diukur dan diterjemahkan menjadi tindakan. Penting untuk menciptakan lingkungan yang kondusif bagi kinerja yang efektif dan efisien yang didukung dengan insentif dan promosi di semua tingkat pemerintahan.

\section{DAFTAR PUSTAKA}

Alimudin, A. (2017). Peran Sistem Manajemen Kinerja, Kompetensi Pegawai dan Promosi Jabatan dalam Meningkatkan Kinerja Pegawai. Jurnal Ekonomi Modernisasi, 13(3), 155-165.

Armstrong, M., \& Baron, A. (2005). Managing Performance: Performance Management in Action. CIPD publishing.

Bititci, U. S., Mendibil, K., Nudurupati, S., Garengo, P., \& Turner, T. (2006). Dynamics of Performance Measurement and Organisational culture. International Journal of Operations \& Production Management.

Cassell, C., Cunliffe, A. L., \& Grandy, G. (Eds.). (2017). The SAGE Handbook of Qualitative Business and Management Research Methods. London: Sage.

Dunleavy, P., \& Hood, C. (1994). From Old Public Administration To New Public Management. Public Money \& Management, 14(3), 9-16. 
Fathya, V. N. (2019). Reformasi Manajemen SDM Aparatur di Indonesia. GOVERNMENT: Jurnal Ilmu Pemerintahan, 10(1), 49-56.

Ferlie, E., \& Steane, P. (2002). Changing Developments in NPM. International Journal of Public Administration, 25(12), 1459-1469.

Kadarisman, M. (2018). Manajemen Aparatur Sipil Negara. Depok: Rajawali Press

Kristiana, T. (2015). Penerapan Profile Matching untuk Penilaian Kinerja Pegawai Negeri sipil (PNS). Jurnal Pilar Nusa Mandiri, 11(2), 161-170.

Marr, B., \& Schiuma, G. (2003). Business Performance Measurement-Past, Present and Future. Management decision, 41(8), 680-687.

Moleong, L. J. (2005). Metode Penelitian Deskriptif Kualitatif. Bandung: Remaja Rosdakarya.

Nunberg, B. (1994). Experience with Civil Service Pay and Employment Reform: An Overview. Rehabilitating government: Pay and employment reform in Africa, 119159.

Osborne, D. G., \& Gaebler, T. T. (1992) Reinventing Government. Read-ing, Mass.: Addison-Wesley.

Peraturan Pemerintah Nomor 46 tahun 2011 tentang Penilaian Prestasi Kerja ASN

Priansa, D. J. (2017). Manajemen Kinerja Kepegawaian dalam Pengelolaan SDM Perusahaan. Bandung: Pustaka Setia

Ruky, A. S. (2002). Sistem Manajemen Kinerja. Jakarta: Gramedia Pustaka Utama.

Schedler, K., \& Proeller, I. (2000). New public management. Stuttgart/Wien.

Soltani, E., Van Der Meer, R., \& Williams, T. M. (2005). A Contrast of HRM and TQM Approaches to Performance Management: Some Evidence. British Journal of Management, 16(3), 211-230.

Sugiyono, P. (2005). Memahami Penelitian Kualitatif. Bandung: Alfabeta.

Undang-Undang Nomor 5 Tahun 2014 tentang Aparatur Sipil Negara.

Wang, X., \& Berman, E. (2001). Hypotheses about Performance Measurement in Counties: Findings from A Survey. Journal of Public Administration Research and Theory, 11(3), 403-428. 